\title{
Increasing Meaningful Assistive Technology Use in the Classrooms
}

\author{
Cynthia Connor, Lawrence A. Beard \\ Department of Curriculum and Instruction, Jacksonville State University, USA
}

Copyright (C) 2015 by authors, all rights reserved. Authors agree that this article remains permanently open access under the terms of the Creative Commons Attribution License 4.0 International License

\begin{abstract}
Although personal technology is consistently used by students and teachers, meaningful use of technology for instruction may not be feasible without providing teachers specific training and support. One university is providing workshops, feedback through coursework, and hands-on training to teacher candidates and local area teachers. In addition, the program trains teachers in appropriate uses of the mini-iPad and lends technology, including mini-iPads and switches with wireless interfaces, for the teacher candidates and interns to use in practicum and internship settings.
\end{abstract}

Keywords Assistive Technology, AT in the Classroom, AT in Higher Education, Mini iPads

\section{Introduction}

Use of educational technology, especially computers, cell phones, tablets, and computer-related peripherals/applications, has grown tremendously and has permeated all areas of our lives. It is incomprehensible that anyone today would argue that banks, hospitals, or any industry should use less technology, but that argument seems to hold true for the public school systems. According to Valdez, [1] most young people cannot understand arguments that schools should limit technology use. For them, use of technology, especially what is usually considered high-tech, plays a major role in not just their education and learning, but in their social relationships with their friends, their families, and their schools.

It should be noted that in the past, society has benefited from innovations that were originally conceived to benefit people with disabilities. For example, captions on television programming were created for people with hearing impairments but are now used by millions of people who need to watch TV in noisy places or with the sound turned off so others are not disturbed. Sidewalk curb cuts, intended at first to help people using wheelchairs negotiate intersections, are a welcome accommodation for the elderly, parents pushing baby strollers, delivery people, and skateboarders. Generally, if a product is designed in a way that it can be used by people with disabilities, whether it be high tech or light tech, it will be a better product for everybody [2]. The line between that which is considered high-tech technology and light-tech assistive technology has not only faded, in some cases it is non-existent. With the advent and popularity of a variety of technology such as the tablet and smart phone, having personal technology devices (PD) in school is no longer just for students with disabilities. In today's schools, owning and/or using personal technology for learning in the classroom may not only be accepted and encouraged, but, in some cases, it is required. Twenty years ago, many of the applications that are standard on PDs today, such as touch screens, voice activation, and text to speech or speech to text were found only in specialized technology for students who required assistance for accessing computers. Now those applications are common to almost all varieties of educational and personal technology. However, making use of available technology for instruction, especially for instruction of students with mild to severe disabilities, requires both knowledge of how the devices can be utilized by the students and willingness on the part of teachers to provide the opportunity for that utilization. As Cave and Brown [3] suggest, teacher quality is the largest factor impacting student learning. It is possible that the more knowledge a teacher possesses of how the students can use PDs for learning in that teacher's domain, the more likely the teacher is to be motivated to provide opportunities within the classroom for students to effectively use technology.

\section{Technology Use in the Classroom}

Many teachers do not use the available technology simply because they lack the understanding of how these devices work or can be used in an educational setting. According to Clifford and Reed, one of the reasons teachers are still challenged is that assistive technology has typically been treated as an isolated, specialized factor understood and implemented by only a few specifically trained individuals 
[4]. To counter this trend, many schools have professional development activities/workshops for all teachers, and, as more systems provide technology to students, there is an increased need for more appropriate, hands-on workshops throughout. However, specialized training in how to utilize technology for individual teacher's instructional needs with general education students and especially for students with mild and in some cases severe disabilities requires much more than a one-time-one-size-fits-all workshop [4]. Despite the absolute best of intentions on the part of device manufacturers and company representatives, theoreticians and authors, one size does not fit all, and we must, as caregivers and teachers, customize the strategy/device to fit the student, NOT the other way around [5]. It is important to remember that for people without disabilities, technology makes things easier. For people with disabilities, the appropriate utilization of well thought out personalized assistive technology makes things possible.

Students say they are motivated by solving real-world problems. They often express a preference for doing rather than listening. Since most educators consider learning-by-doing the most effective way to learn [6], students need to be taught using a hands on-minds on approach. Using this technique, students are actually allowed to perform the task as they construct meaning and acquire understanding (hands-on) as well as focus on core concepts helping develop thinking processes and encouraging them to question and seek answers and thereby acquire an understanding of the how the concept will be applied in real life situations.

\section{Teacher Training}

Teacher training should ensure the effective integration of classroom technology. The current school curriculum tends to guide teachers in training students to be autonomous problem solvers [7]. This can become a significant barrier to effective teacher training programs because the traditional methods of teaching are not consistent with what is now expected in the present workplace. These workplace experiences are not emphasized in the traditional classroom, but are twenty-first century workplace skills that can be attained through the incorporation and engagement with technology[8]. Changes in how we deliver instruction and effective utilization of technology can also promote a higher level of learning among all students, including students with disabilities [9]. Technology is a means to the end in education and educators must have a good grasp of the technology being used and its advantages over more traditional methods. If there is a lack in either of these areas, technology be a hindrance rather than benefit to teaching.

The ever evolving nature of technology may unsettle teachers who may perceive themselves as perpetual novices and in a consistent catch up mode [10]. The ways in which teacher education programs teach future educators to use technology is also outdated. The primary focus of most training programs is on computer literacy, rather than the understanding and mastery of technology for information processing, communication, and problem solving [11]. New resources have to be designed and distributed whenever the technological platform has been changed. However, finding quality materials to support classroom objectives after such changes is often difficult. Random professional development days are inadequate [12].

Teachers may not feel the need to change the traditional education system because it has been successful in the past. However, just because we have always done it one way does not necessarily mean it is the right way to teach for the current and future generations of students. Learning styles and the methods of collecting information have evolved, and students often feel disassociated from the teaching styles of the teacher and the available technology [7].

One potential place a teacher can develop problem solving skills to utilize technology is in the school of education where he or she receives their undergraduate or graduate teaching degree. However, to be comfortable with utilization of any technology, the teacher needs the opportunity for hands-on practice in the both the university and real world classroom, usually done during practica. Unfortunately, not all school systems have the same degree of technology available, and should a teacher candidate be placed for practicum in one of the schools lacking resources, the opportunity for practice is limited [13]. For this reason, it is important to be able to provide the practicum teacher candidate or intern student teacher with the skills and tools necessary to integrate technology for his or her specific teaching needs. This training should include not only hands-on skill building, but real world practical experiences. Thus not only will the teacher benefit, but also the students the teacher serves during both the current placement and in the future.

One such program at a small university provides the training and the technology for undergraduate and graduate teacher candidates. Through an in-house university grant, a program was developed to provide not only needed training to teacher candidates, but the technology for them to use in field experience. This program lends mini-iPads [14] with appropriate learning apps downloaded by undergraduate and graduate teacher candidates. Should the teacher candidates instruct students for whom traditional iPad input is not an option, iPad wireless switch interfaces [15] and switches, either purchased or made by students, are available for use as well. Training workshops are provided on campus to teacher candidates, university faculty, and any local teachers who may wish to attend. The workshops are then followed up with either continuous feedback to the teacher candidates via coursework or in-classroom hands-on training when requested by a teacher. In both cases, the emphasis is on how the teachers and/or teacher candidates can successfully integrate the assistive technology to positively impact student learning. 


\section{Program Implementation}

In the first semester of the grant, both an intern and practicum teacher candidate checked out and utilized the mini-iPads and/or switch interfaces with their practicum students. The students in the intern's classroom were able to utilize a classroom iPad in a new way with the use of the switch interface. Although switches were also borrowed, there was a classroom switch available which, due to a lack of teacher training, had not been utilized previously during the time the intern was in the classroom. The intern was able to plan and implement a lesson using the devices and receive feedback from one of the co-directors of the grant. In addition, practicum students were allowed to check out the mini-iPad to use with students at school settings with limited technology available.

\section{Conclusions}

The results of this project are very promising. Not only are teachers and teacher candidates being trained in the use of current technology and in the development of inexpensive alternative switches for classroom use, these methodologies are being utilized in the public school classroom setting. Therefore, students with disabilities will benefit from the increased use of accessible technology linked to college and career and functional standards, and teacher graduates will be able to utilize this technology when they begin to accept teaching positions after graduation.

\section{REFERENCES}

[1] Valdez, G. (2005). Critical issue: Technology: A catalyst for teaching and learning in the classroom. North Central Regional Educational Laboratory. Retrieved from: http://www.ncrel.org/sdrs/areas/issues/methods/technlgy/te6 00.htm May 25, 2015.

[2] Scadden, L. A. (2001). Enabling science. The Science Teacher, 68(7), 48-51.

[3] Cave, A., and Brown, C. W. (2010). When learning is at stake: Exploration of the role of teacher training and professional development schools on Elementary Students' Math Achievement. National Forum of Teacher Education Journal, 20(3), 1-21.
[4] Clifford, M., and Reed, P. (2004). Critical issue: Enhancing system change and academic success through assistive technologies for K-12 students with special needs. North Central Regional Educational Laboratory. Retrieved from: http://www.ncrel.org/sdrs/areas/issues/methods/technlgy/te7 00.htm, May 25, 2015.

[5] Lambert, J., Gong, Yi., and Cuper, P. (2008). Technology, transfer, and teaching: The impact of a single technology course on preservice teachers' computer attitudes and ability. Journal of Technology and Teacher Education, 16(4), 385-410.

[6] Carpenter, L., Johnston, L., and Beard, L. (2015). Assistive technology: Access for all students, (3rd. ed.). Upper Saddle River, NJ: Pearson.

[7] Lombardi, M. M. (2007). (www.educause.edu/ir/library/pdf/ELI3009.pdf).

[8] Oliver, A.; Osa, J. O.; Walker, T. M. (2012). "Using instructional technologies to enhance teaching and learning for the 21 st century pre K-12 students: The case of a professional education programs unit". International Journal of Instructional Media 39 (4): 283-295.

[9] Jenkins, H. (2009). Confronting the Challenges of Participatory Culture: Media Education for the 21st Century. Cambridge, MA: The MIT Press.

[10] De Castell, S. (2011). Ludic Epistemology: What Game-Based Learning Can Teach Curriculum Studies. Journal of the Canadian Association for Curriculum Studies, 8 (2), 19-27.

[11] Robinson, T. (2006). Schools Kill Creativity. TED Talks. [Video]. Retrieved on August 6, 2015 from http://www.ted.com/talks/lang/en/ken_robinson_says_school s_kill_creativity.html

[12] Hohlfeld, T. N., Ritzhaupt, A. D., Barron, A. E., and Kermker, K. (2008). Examining the digital divide in k-12 public schools: Four-year trends for supporting ICT literacy in Florida. Computers and Education, 51(4), 1648-1663.

[13] Harris, J., Mishra, P., \& Koehler, M. (2009). Teachers' Technological Pedagogical Integration Reframed. Journal of Research on Technology in Education, 41 (4), 393-416.

[14] Connor, C., Snell, M. E., Gansneder, B., and Dexter, S. L. (2010). Special education teachers' use of assistive technology with students who have severe disabilities. Journal of Technology and Teacher Education, 18(3), 369-386.

[15] Mini-iPad (2015). Apple, Inc. http://www.apple.com

[16] iPad Wireless Interface (2015). Enabling devices. https://enablingdevices.com. 